\title{
Short Note \\ Report of a mummified leopard seal carcass in the southern Dry Valleys, McMurdo Sound, Antarctica
}

\author{
JONATHAN C. BANKS ${ }^{1 *}$, PHILIP M. ROSS ${ }^{1}$ and TRACY E. SMITH ${ }^{\mathbf{2}}$ \\ ${ }^{I}$ Department of Biological Sciences, The University of Waikato, Private Bag 3150, Hamilton 3240, New Zealand \\ ${ }^{2}$ Department of Biology, Colorado State University, $200 \mathrm{~W}$ Lake Street, Fort Collins, CO 80523-1878, USA \\ *jbanks@waikato.ac.nz
}

Received 18 May 2009, accepted 6 July 2009

\section{Introduction}

The wide spread occurrence of mummified seal and penguin carcasses tens of kilometres from the open ocean is an interesting phenomenon occurring in the Antarctic Dry Valleys. Mummified seal carcasses were first reported by Scott's expedition in 1903 (Scott 1969), and live seals and seal carcasses have since been reported many kilometres from the nearest ice-free ocean. For example, Stirling \& Rudolph (1968) reported a live crabeater seal near Mount Saunders, Marie Byrd Land, $113 \mathrm{~km}$ from the open ocean.

Seal carcasses found in the McMurdo Dry Valleys are predominantly crabeater seals (Lobodon carcinophaga (Hombron \& Jacquinot)) with a smaller number of Weddell seals, (Leptonychotes weddellii (Lesson)), also reported. For example, Barwick \& Balham (1967) found six mummified Weddell seal carcasses and 115 crabeater seal carcasses in the Wright and Victoria valley systems. There has also been a single report of an elephant seal, Mirounga leonina (L.) skeleton found buried in marine terrace deposits at Marble Point near the mouth of the Taylor Valley (Nichols 1966). Here we present only the second published report of a leopard seal carcass from the McMurdo Dry Valleys.

\section{Method and results}

In January 2009, a leopard seal carcass (Hydrurga leptonyx (de Blainville)) was found $c$. $500 \mathrm{~m}$ from the foot of the Garwood Glacier in Garwood Valley at $78^{\circ} 01.341^{\prime} \mathrm{S}$, $164^{\circ} 02.669^{\prime} \mathrm{E}$. The seal was located $141 \mathrm{~m}$ above sea level with the nearest ice covered ocean $5.63 \mathrm{~km}$ to the east and the nearest ice free ocean $c .50 \mathrm{~km}$ away (measured at the height of summer). Identification of the carcass was confirmed by Anton van Helden, marine mammal curator at Te Papa/Museum of New Zealand, from photographs. Diagnostic features were the specimen's teeth and the marked constriction at its neck (Figs $1 \& 2$ ).

The nose to tail length of the animal was $1.8 \mathrm{~m}$ suggesting that the carcass was a first year juvenile as fully grown adults can reach up to $4.5 \mathrm{~m}$ in length (Laws 1993). The carcass appeared relatively intact with no obvious signs of injury. The absence of fur (Figs $1 \& 2$ ) is probably due to abrasion from aeolian material and indicates that the animal probably died several years ago. It was not possible to determine the sex of the animal as we did not have the necessary permits to disturb the carcass.

\section{Discussion}

We are aware of only one previously published report and/ or occurrence of a mummified leopard seal carcass and that was found in the "ice free land of McMurdo Sound" (Péwé et al. 1959). It is possible that this was actually Garwood Valley as Dort (1971) reports that Péwé found 20 mummified carcasses in and near Garwood Valley. However, Péwé et al. (1959) report that the identity of their leopard seal was confirmed "from a lower jaw of the carcass" suggesting that the jaw was removed for identification. The carcass we found appeared complete. However, it is possible that this is the same individual. Nevertheless, we can now provide precise coordinates for the location of a leopard seal carcass.

Stirling \& Kooyman (1971) suggest that crabeater seals are more likely than leopard and Weddell seals to enter the McMurdo Dry Valleys and become mummified carcasses due to differences in behaviour between the three species. Crabeaters are more numerous at the head of McMurdo Sound and are also more agile on land. However, the leopard seal carcass in Garwood Valley is a considerable

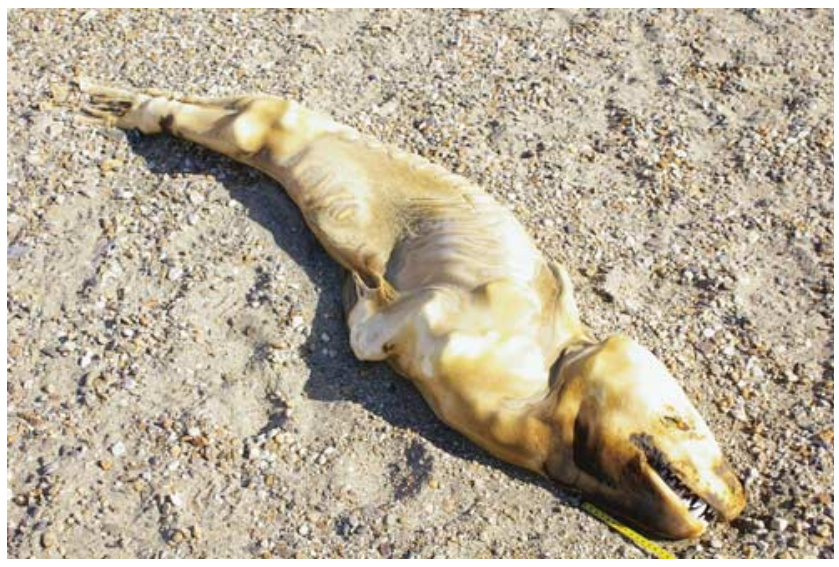

Fig. 1. Leopard seal carcass, Garwood Valley, McMurdo Sound, Antarctica. 


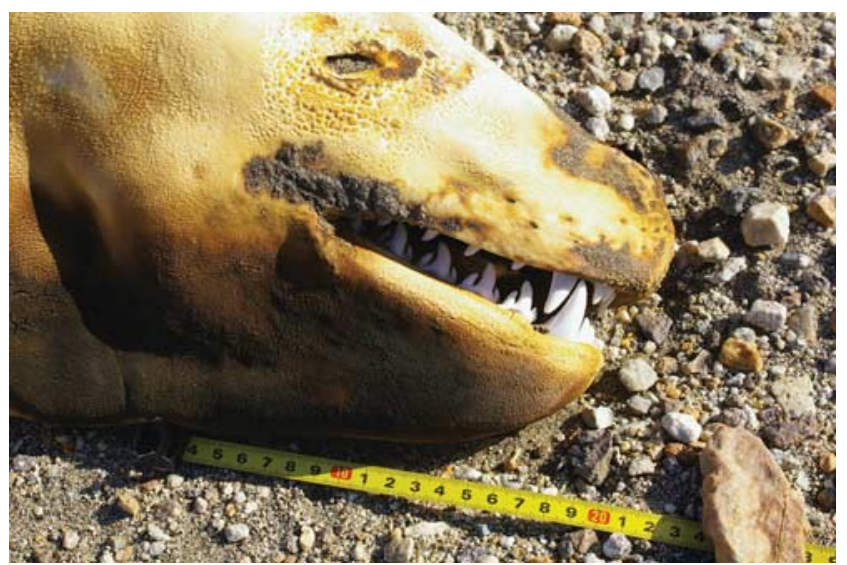

Fig. 2. Close up of the distinctive leopard seal teeth.

distance from open water suggesting that leopard seals may be considerably more agile and able to travel longer distances over land than previously thought. It seems possible therefore, that the paucity of mummified leopard seal carcasses in the McMurdo Dry Valleys may also reflect the relative abundances of each species; there are an estimated 204000 crabeater seals, 32000 Weddell seals and 8000 leopard seals in the Ross Sea (Ainley 1983).

\section{Acknowledgements}

Our research in the southern Dry Valleys was part of the International Polar Year project, "Understanding, Valuing and Protecting Antarctica's Unique Terrestrial Ecosystem: Predicting Biocomplexity in Dry Valley Ecosystems" and was supported by the Foundation for Research Science and Technology (UOWX0701), The University of Waikato Vice Chancellor's fund and Antarctica New Zealand. We thank Ian Hogg for helpful comments on this manuscript.

\section{References}

Ainley, D.G. 1983. Biomass of birds and mammals in the Ross Sea. In Siegfried, W.R., Convey, P.R. \& Laws, R.M., eds. Antarctic nutrient cycles and food webs. Berlin: Springer, 498-515.

Barwick, R.E. \& Balham, R.W. 1967. Mummified seal carcases in a deglaciated region of South Victoria Land, Antarctica. Tuatara, 15, $165-180$.

DorT, W. 1971. Mummified seals of southern Victoria Land. Antarctic Journal of the United States, 6(5), 210-211.

Laws, R.M. 1993. Identification of species. In Laws, R.M., ed. Antarctic seals. Research methods and techniques. Cambridge: Cambridge University Press, 1-28.

Nichols, R.L. 1966. Geomorphology of Antarctica. Antarctic Research Series, 8, 1-46.

PÉwÉ, T.L., Rivard, N.R. \& Llano, G.A. 1959. Mummified seal carcasses in the McMurdo Sound region, Antarctica. Science, 130, 716.

ScotT, R.F. 1969. The Voyage of the Discovery. New York: Greenwood Press, 508 pp.

StiRling, I. \& Kooyman, G.L. 1971. The crabeater seal (Lobodon carcinophagus) in McMurdo Sound, Antarctica, and the origin of mummified seals. Journal of Mammalogy, 52, 175-180.

Stirling, I. \& RUdolph, E.D. 1968. Inland record of a live crabeater seal in Antarctica. Journal of Mammalogy, 49, 161-162. 